\title{
Commentary \\ A call to arms to reduce premature deaths by using inexpensive resuscitation care
}

\author{
Sam A Warren and Graham Nichol
}

\begin{abstract}
Harborview Medical Center and University of Washington-Harborview Center for Prehospital Emergency Care, University of Washington, 325 Ninth Ave, Seattle, WA 98104, USA
\end{abstract}

Corresponding author: Sam A Warren, sawarren@u.washington.edu

Published: 19 August 2008

This article is online at http://ccforum.com/content/12/4/173

(C) 2008 BioMed Central Ltd

See related research by Graf et al., http://ccforum.com/content/12/4/R92
Critical Care 2008, 12:173 (doi:10.1186/cc6970)

How much to pay for a health intervention is a poignant question most societies have yet to answer formally. Such decisions are complex and are predicated not only on the absolute and incremental cost of the intervention but also on the quantity and quality of effectiveness data related to the intervention. Countries with a centralized planning process for health care may imply their answer when they approve or disapprove for national formulary a drug designed to extend life in a terminal disease. The UK's National Health Service recently declined approval of bevacizumab (Avastin, with a cost of therapy per year of approximately $\$ 100,000$ ) as firstline therapy for lung and breast cancer [2]. In the US, there appears to be a general consensus that $\$ 50,000$ to $\$ 100,000$ per year of life gained is acceptable [3]. An analysis based on economic principles suggested that we should be willing to spend up to twice the average annual income on health care [4]. In this light, less than 15,000 euros per QALY for intensive care after resuscitation from cardiac arrest is similar to or less than the cost of other commonly used medical interventions.

This study has some limitations relative to current standards for economic evaluation of health interventions [5]. It was performed in a single institution in a single country. The application of post hoc subgroup analysis based on neurologic status tended to underestimate the costs and overestimate the cost-effectiveness of the program. Restricting the analysis to consider a health care rather than a societal perspective underestimated costs and made it difficult to compare the results of this analysis with comprehensive economic evaluations of health care and other interventions. However, such limitations are unlikely to change the central messages of the study. These are that quality of life after

$\mathrm{OHCA}=$ out-of-hospital cardiac arrest; $\mathrm{QALY}=$ quality-adjusted life year. 
resuscitation from cardiac arrest is good and that the costs of care after resuscitation are acceptable.

The study of Graf and colleagues is a timely one. Survival after out-of-hospital cardiac arrest (OHCA) has been static over time [6], but a recent analysis suggests that outcomes are improving [7]. Therapeutic hypothermia [8,9] is likely to be the first of several effective hospital-based interventions for cardiac arrest [10-12]. However, adoption of hypothermia has been slow [13]. The perceived poor prognosis and expense of care of patients resuscitated from cardiac arrest are key barriers to the implementation of effective therapies such as cooling. We need to change the culture of resuscitation and recognize that cardiac arrest is a treatable condition that is associated with good quality of life after resuscitation as well as acceptable costs of care.

In many countries, a high percentage of health care costs occur in the last year of life. Imminent death is not always predictable, and a persistent vegetative state is associated with poor quality of life. Therefore, we require better methods of predicting who will recover and who will have disability after resuscitation from cardiac arrest [14], especially in the era of hypothermia.

Two hundred seventy thousand people experience OHCA each year in the US (G. Nichol, unpublished data). About 450,000 do so in Europe based on extrapolation from population-based incidence estimates [15]. Only 7\% of those with OHCA survive to discharge [16]. If we double survival after OHCA, then 18,900 premature deaths in the US and 31,500 in Europe would be averted each year. There are many ways to improve the chain of survival, including improved communications from citizens to emergency medical services, delivery of care to the patient, delivery of the patient to the hospital, and delivery of cardiac and critical care once there. The time has come for us to come together to do so.

\section{Competing interests}

SAW is a member of the American Heart Association (AHA) (Dallas, TX, USA) National Registry for Cardiopulmonary Resuscitation Adult Research Task Force. GN is a member of the AHA Advanced Cardiac Life Support Subcommittee, the Scientific Advisory Board of the AHA National Registry for Cardiopulmonary Resuscitation, and the Board of Directors of the Medic One Foundation (Seattle, WA, USA). He has received grants from the National Institutes of Health (Bethesda, MD, USA) for the Resuscitation Outcomes Consortium (2004-2009), the Laerdal Foundation for Acute Medicine (Stavanger, Norway) for a randomized trial of a CPR training aid (2007), and the Canadian Institutes of Health Research (Ottawa, ON, Canada) and Medtronic Inc. (Minneapolis, MN, USA) for a randomized trial of a resynchronization therapy (2005-2009). He has received equipment, including mannequins (Laerdal Medical, Stavanger, Norway) and monitor/defibrillators (Physio-Control Inc., a division of Medtronic, Redmond, WA, USA), donated to support overseas medical missions. Travel expenses were provided to him by INNERCOOL therapies Inc. (San Diego, CA, USA) and Radiant Medical Inc. (Redwood City, CA, USA) for single trips in 2006. He consulted for Northfield Laboratories Inc. (Evanston, IL, USA) and Paracor Medical Inc. (Sunnyvale, CA, USA) in 2007.

\section{References}

1. Graf J, Mühlhoff C, Doig GS, Reinartz S, Bode K, Dujardin R, Koch KC, Roeb E, Janssens U: Health care costs, long-term survival, and quality of life following intensive care unit admission after cardiac arrest. Crit Care 2008, 12:R92.

2. Hirschler B, Reid K, Thompson A: NICE rejects cancer drug in clash with Roche [http://uk.reuters.com/article/allBreakingNews/ idUKL2645842120080626].

3. Talmor D, Shapiro N, Greenberg D, Stone PW, Neumann PJ: When is critical care medicine cost-effective? A systematic review of the cost-effectiveness literature. Crit Care Med 2006, 34:2738-2747.

4. Garber AM, Phelps CE. Economic foundations of cost-effectiveness analysis. J Health Economics 1997, 16:1-31.

5. Gold MR, Siegel JE, Russell LB, Weinstein MC: Cost-Effectiveness in Health and Medicine. New York: Oxford University Press; 1996.

6. Rea TD, Helbock M, Perry S, Garcia M, Cloyd D, Becker L, Eisenberg $M$ : Increasing use of cardiopulmonary resuscitation during out-of-hospital ventricular fibrillation arrest: survival implications of guideline changes. Circulation 2006, 114:27602765.

7. Hollenberg J, Herlitz J, Lindqvist J, Riva G, Bohm K, Rosenqvist M, Svensson L: Improved survival after out-of-hospital cardiac arrest is associated with an increase in proportion of emergency crew-witnessed cases and bystander cardiopulmonary resuscitation. Circulation 2008, 118:389-396.

8. The Hypothermia after Cardiac Arrest Study Group: Mild therapeutic hypothermia to improve the neurologic outcome after cardiac arrest. $N$ Engl J Med 2002, 346:549-556 [erratum in: $N$ Engl J Med 2002, 346:1756].

9. Bernard SA, Gray TW, Buist MD, Jones BM, Silvester W, Gutteridge G, Smith K: Treatment of comatose survivors of out-ofhospital cardiac arrest with induced hypothermia. $N$ Engl J Med 2002, 346:557-563.

10. Laurent I, Adrie C, Vinsonneau C, Cariou A, Chiche JD, Ohanessian A, Spaulding C, Carli P, Dhainaut JF, Monchi M: High-volume hemofiltration after out-of-hospital cardiac arrest: a randomized study. J Am Coll Cardiol 2005, 46:432-437.

11. Sunde K, Pytte M, Jacobsen D, Mangschau A, Jensen LP, Smedsrud C, Draegni T, Steen PA: Implementation of a standardised treatment protocol for post resuscitation care after out-ofhospital cardiac arrest. Resuscitation 2007, 73:29-39.

12. Keelan PC, Bunch TJ, White RD, Packer DL, Holmes DR Jr.: Early direct coronary angioplasty in survivors of out-of-hospital cardiac arrest. Am J Cardio/ 2003, 91:1461-1463, A6.

13. Merchant RM, Soar J, Skrifvars MB, Silfvast T, Edelson DP, Ahmad F, Huang KN, Khan M, Vanden Hoek TL, Becker LB, Abella BS: Therapeutic hypothermia utilization among physicians after resuscitation from cardiac arrest. Crit Care Med 2006, 34:1935-1940.

14. Pfeifer R, Borner A, Krack A, Siqusch HH, Surber R, Fiqulla HR: Outcome after cardiac arrest: predictive values and limitations of the neuroproteins neuron-specific enolase and protein S-100 and the Glasgow Coma Scale. Resuscitation 2005, 65:49-55.

15. de Vreede-Swagemakers JJ, Gorgels AP, Dubois-Arbouw WI, van Ree JW, Daemen MJ, Houben LG, Wellens HJ: Out-of-hospital cardiac arrest in the 1990's: a population-based study in the Maastricht area on incidence, characteristics and survival. $J$ Am Coll Cardiol 1997, 30:1500-1505.

16. Nichol G, Stiell IG, Laupacis A, Pham B, De Maio V, Wells GA: A cumulative meta-analysis of the effectiveness of defibrillatorcapable emergency medical services for victims of out-ofhospital cardiac arrest. Ann Emerg Med 1999, 34:51 7-525. 